\title{
The Policy of Kuningan District Regional Government in the Efforts to Prevent Human Trafficking
}

\author{
Haris Budiman \\ Faculty of Law, University of Kuningan, Indonesia \\ E-mail: budiman09@yahoo.co.id
}

How to cite : Budiman, Haris. (2018). The Policy of Kuningan District Regional Government in the Efforts to

Prevent Human Traffiking . UNIFIKASI : Jurnal Ilmu Hukum, 5(2), 119-124. DOI :

10.25134/unifikasi.v5i2.1073

Submitted : 21-04-2018 Revised : 03-08-2018 Accepted : 29-08-2018

\begin{abstract}
The era of regional autonomy has made regions strive to utilize their potential for the sake of community's welfare. Yet, the limited job opportunities cause the job seekers to work abroad which results in various legal cases, including human trafficking. The purpose of this research is to analyze the regulations on human trafficking, the factors causing human trafficking, and the role of regional government in preventing human trafficking. The research method used was non-doctrinal. The results showed that human trafficking has been regulated in various regulations, but in practice, the regulations are not well implemented because of various factors, including economic, social, and cultural factors. Moreover, the policy of Kuningan District Regional Government in the efforts to prevent human trafficking is limited to the forming of Integrated Service Center for Empowering Women and Children (P2TP2A) which in its implementation has not run optimally due to limited funds and participation from the community.
\end{abstract}

Keywords: regional policy, human trafficking, criminal acts

\section{Kebijakan Pemerintah Daerah Kabupaten Kuningan dalam upaya Menanggulangi Perdagangan Manusia}

\begin{abstract}
Abstrak : Era otonomi daerah menjadikan daerah berupaya untuk memanfaatkan potensi yang dimilikinya dalam rangka mensejahterakan masyarakat. Akan tetapi keterbatasan lapangan kerja menyebabkan tingginya para pencari kerja untuk bekerja di luar negeri, sehingga menimbulkan berbagai kasus hukum, diantaranya perdagangan manusia. Rumusan masalah: bagaimana pengaturan tentang perdagangan manusia, faktor-faktor apa yang menjadi penyebab terjadinya perdagangan manusia, serta bagaimana peran pemerintah daerah dalam mencegah terjadinya Perdagangan manusia. Metode penelitian yang digunakan bersifat non doktrinal dengan pendekatan yuridis empiris. Pengaturan perdagangan manusia telah diatur dalam berbagai perundang-undangan namun dalam pelaksanaannya tidak berjalan dengan optimal karena ada faktor yang mempengaruhi. Faktor-faktor tersebut antara lain faktor ekonomi, faktor sosial dan faktor budaya. Kebijakan Pemerintah Daerah Kabupaten Kuningan dalam upaya mencegah perdagangan manusia baru sebatas membentuk Pusat Pelayanan Terpadu Pemberdayaan Perempuan dan Anak (P2TP2A). yang dalam pelaksanaannya belum berjalan optimal karena keterbatasan dana dan partisipasi dari masyarakat.
\end{abstract}

Kata Kunci : kebijakan daerah, perdagangan orang, tindak pidana

\section{INTRODUCTION}

In regional autonomy era, regions as a single legal community have the authority to regulate and manage their households in accordance with their community's aspirations and interests as long as they do not conflict with the national law and the public interest. The principle of regional autonomy uses the principle of autonomy as broadly as possible, which includes establishing regional policies to provide services, increasing participation, initiatives and community empowerment aimed at improving community's welfare. Therefore, since the enactment of regional autonomy, regions have strived in various ways to manage and utilize their potential for the sake of community's welfare.

Yet, the development of technology and information and the era of globalization bring challenges and changes in all sectors of life so that it demands quality and professional human resources. This condition causes job seekers who have limited knowledge and skills to be marginalized because of the difficulty of competing with professional human resources. 
The limited job opportunities in the country have an impact on job seekers' choice to work abroad. This condition may reduce the employment problem, but it may also cause various kinds of legal problems in which one of them is human trafficking. According to Farhana, as cited in Kuncoro, there are eleven districts in Java known as suppliers of women for trafficking in history, namely West Java (Indramayu, Karawang, Kuningan), Central Java (Pati, Jepara, Wonogiri), and East Java (Blitar, Malang, Banyuwangi , and Lamongan $)^{1}$

As a district with the lowest local income (PAD) in West Java, the unemployment rate in Kuningan District is still high. Until 2015 , the number of unemployment reached 32.118 people coming from urban and rural areas. Unemployment in urban areas reaches 14.998 people, while in rural areas, it reaches 17.120 people. In addition, based on educational background, elementary school graduates who are unemployed reach 9.225 people, and for junior high school graduates reach 9.857 people. The biggest number of unemployment is high school graduates that reach 11.705 people. Moreover, the number of unemployment for university graduates reaches 1.331 people. $^{2}$

According to the Head of the Social and Manpower Office of Kuningan District, there are currently 24.817 people who are looking for jobs, while the market absorption is only 4.091 for the existing 695 companies. ${ }^{3}$ The data shows that the opportunity to get a decent job in Kuningan District is quite small so that many job seekers look for jobs in other places, including abroad. Yet, in reality, the workers who work abroad face various problems, including becoming the object of human trafficking, slavery, forced labor, violence, arbitrariness, crimes of human dignity, and violation of human rights. Meanwhile, the government with various limitations has not been able to guarantee and protect the human rights of the citizens who work abroad based on the principle of rights equality, democracy, social justice, gender equality and justice, antidiscrimination, and anti-human trafficking. Based on the description above, the formulation

\footnotetext{
1 Terence H Hull, Endang S, Gavin W Jones, Pelacuran di Indonesia, cetakan I, Jakarta, Pustaka Sinar Harapan, 1997, pp. 1

${ }^{2}$ Keterangan Kepala Dinas Sosial dan Tenaga Kerja kabupaten Kuningan, sebagaimana dimuat dalam HU Radar Cirebon tanggal 7 Maret 2016.pp. 2

${ }^{3} \mathrm{HU}$ radar Cirebon, 7 Maret 2016
}

of the problems that become the main focus of the research are:

a. What are the regulations and scope of human trafficking in Indonesia?

b. What are the factors causing human trafficking in Indonesia?

c. What are the roles of the Regional Government in preventing human trafficking in Kuningan District?

\section{METHOD}

The method used in this research is non-doctrinal research method because seeing the law is not only conceptualized as the whole principles and rules governing human life in society, but also includes institutions and processes that realize the implementation of the rules in society. Thus, this research tries to see the relationship between legal factors with extra-legal factors relating to the object under study. The approach used in this research is socio-legal because it combines normative and sociological approaches. This research focuses on the implementation of Local Government policies in preventing human trafficking in Kuningan District.

\section{RESULTS AND DISCUSSION \\ The Regulations and Scopes of Human Trafficking in Indonesia}

Law Number 13 of 2003 concerning Manpower regulates the placement of workers. This worker placement problem must be regulated by a separate regulation. The regulation concerning the placement of workers abroad is stated in Law Number 39 of 2004 concerning the placement and protection of Indonesian workers abroad. Yet, unfortunately, the contents of this law only regulate the procedures for the placement of workers abroad, while the regulation of rights and guarantees of workers protection is only included in a few articles. ${ }^{4}$ This condition becomes the cause of unclear efforts to prevent human trafficking.

In Indonesia, the regulation on human trafficking is stated in Law Number 21 of 2007 concerning the Eradication of Crimes against Human Trafficking. In this Law, Human Trafficking is an act of recruiting, transporting, storing, transferring, or receiving someone with

\footnotetext{
${ }^{4}$ Kamudin, Implementasi Kebijakan Perdagangan Orang,Jurnal Ilmu Hukum Hermeneutika, Jilid 1 Nomor 1, Desember 2015, pp.
} 
the threat of violence, the use of violence or vulnerable positions, entrapment of people, or paying and benefiting others, whether inside the country or between countries for the purpose of exploitation or result in exploited people.

Law Number 21 of 2007 also

formulates the scope of Human Trafficking criminal acts, namely:

a. Every action or series of actions fulfilling the elements of a criminal act specified in this Law.

b. Bringing Indonesian citizens to outside of the territory of NKRI for the purpose of exploitation.

c. Adopting a child by promising or giving something for the purpose of exploitation.

d. Sending children into or out of the country in any way and every person who utilizes victims of Human Trafficking by means of sexual intercourse.

e. Employing victims for the purpose of exploitation or taking advantage on them.

f. Everyone who gives or inserts false information on State documents or other documents to facilitate Human Trafficking.

g. Everyone who gives false testimony, conveys false evidence, or influences the witness to resist the law.

h. Everyone who physically attacks the witness or court officials in Human Trafficking case. Everyone who prevents, blocks, or foils the investigation, prosecution and trial of the accused or the witness directly or indirectly in Human Trafficking case.

i. Everyone who gives the identity of a witness or victim even though it should be kept secret.

Government Regulation Number 9 of 2008 concerning integrated service procedures and mechanisms for witnesses or victims of Human Trafficking (TPPO) explains that an Integrated Service Center should be established in each region and its implementation is regulated in Presidential Regulation Number 69 of 2008 concerning TPPO Prevention and Management Task Force. The results of field observation show that the traffickers work very neatly and organized. They generally search for victims in various ways, such as luring potential victims with various efforts. Some of the traffickers directly contact the potential victims or use other methods such as by using the mode of sending labor, either between regions or countries. The transfer, departure, acceptance, and the shelter are carried out very neatly so that it cannot be detected by the applicable system, even some of them are protected by officials (government and law enforcement officials). Of the various incidents in TPPO, the victims' losses and suffering are caused by the recruitment process carried out by brokers ${ }^{5}$. The brokers approach the potential victims' family or parents. Most of the potential victims are women starting at 11 years old. In this case, there are some parents who give permission to their children. The parents who give permission are then given some money which is generally calculated by traffickers as debts of the potential victims. Yet, there are also parents who refuse to give permission. In this case, if the potential victim is successfully persuaded, then the trafficker will take her away silently. Many of them are successful in improving the economy of their family and they are used as examples for women who left their homes to improve the economy. The next step is the manipulation of documents. Human trafficking victims are generally given an identity card (KTP or passport) in which their name, age and address are manipulated. In several regions of Indonesia, there are many brokers/agents who carry a suitcase containing a deck of KTP, birth certificate, passport, and other forms, complete with name, adult age, and certain addresses. Several aspects that have not been filled in are only the passport and signature to be filled by the (candidate) victims. Besides, there is also confinement before leaving. The traffickers/brokers/sponsors generally do not immediately send the potential victims of human trafficking so that violence and confinement often occurred in which the victims often experience inhumane treatment in shelters.

\section{Factors causing human trafficking}

Human trafficking in Kuningan District generally begins with a mode to be employed in entertainment places or to become household assistant. Several factors causing human trafficking are as follows.

1. Economic Factor

According to Farhana, economic factor is the cause of human trafficking that is motivated by poverty and inadequate job opportunities with a large population. Besides poverty, the gap on welfare level between countries also

\footnotetext{
${ }^{5}$ Ibid, pp.99
} 
causes human trafficking. Countries that are listed as recipients of human trafficking are relatively more prosperous than Indonesia, such as Malaysia, Singapore, Hong Kong, Korea, Saudi Arabia, and etc. In some regions in Indonesia, even though the population is poor, the community has a consumptive lifestyle, especially when performing a wedding celebration which is usually equipped by entertainment. This event usually occurs during the harvest season, when they get a high income and at the same time, the event becomes a thanksgiving event. In every celebration event, such as marriage and circumcision, entertainment should always be held. This type of entertainment shows the level of socio-economic status of parents.

\section{Social Factor}

The occurrence of a prolonged conflict causes people to try to find new areas which results on migration from their hometown with the hopes of gaining a more prosperous life. Therefore, these people are very vulnerable to trafficking. This migrant process is a form of migration carried out with pressure because, in practice, they are recruited through various forms of fraud, including through marriage to be subsequently taken to other countries with the purpose of being trafficked. Poverty is the main driving factor causing human trafficking, but this is not the only factor because there are also citizens and children who prefer to work as farm laborers and have elementary education. For the poor, making money is considered as a way to overcome poverty as well as get some financial benefits. First, they can free from the obligation to fulfill the living needs of their child or wife. Second, they can obtain financial benefits.

Village children are not only in a bad environment, but they are also seen as inappropriate when measured by children's rights. Parents still think that women should only be in domestic territory. Girls do not need to go to high school because in the end, they will return to home and serve their husband. This condition results on high school dropout rates and girls then become migrant as well as domestic workers (household assistants).

3. Cultural Factor

Culture basically includes values that underlie the applicable law. Values are abstract conceptions of what is considered good or bad. Legal culture is the same general assumption of certain communities regarding legal phenomenon. This assumption is a unified view of legal values and behavior. Thus, legal culture shows individual behavior pattern as a member of society who describes the same (orientation) assumption to the legal life that is lived by the community concerned. ${ }^{6}$

Kuningan District society, as other societies in Indonesia, still recognizes the existence of customary law. Customary Law is a law applied in society. ${ }^{7}$ The simple living conditions of society due to inability and loss of access to the resources they possess, lead to the birth of a negative legal culture. In a family, women are always educated to be willing to sacrifice for families, so that many women work not to actualize themselves but to help their families. Therefore, girls are vulnerable to human trafficking.

\section{The roles of the regional government in preventing human trafficking in Kuningan District}

In general, the government's efforts to prevent and overcome human trafficking are stated in various legislations, including Law Number 21 of 2007 concerning the Eradication of Human Trafficking (PTPPO), the Establishment of Integrated Service Centers based on Government Regulation Number 9 of 2008 concerning the procedures and mechanisms of integrated services for witnesses or victims of TPPO, the formation of PTPPO Task Force consisting of various elements of government and society (Presidential Regulation Number 69 of 2008 concerning Task Force for TPPO Prevention and Handling), and the drafting of Regional Regulation in Human Trafficking.

Meanwhile, the Regional Government Policy of Kuningan District in an effort to prevent human trafficking has not been carried out optimally. Up to now, there has not been a Local Regulation that explicitly protects the society from human trafficking. Even if there is a regulation, it is still in the form of a District Head's Decree concerning the Establishment of an Integrated Service Center for Empowering Women and Children (P2TP2A). This institution is a forum for women and children in an effort to provide information and services in the fields of education, health, economy,

\footnotetext{
${ }^{6}$ Hilman Hadikusuma, Antropologi Hukum Indonesia,(Bandung, Penerbit Alumni, 1986).pp.51

7 Umar Said Sugiarto, Pengantar Hukum Indonesia, (Jakarta, Sinar Grafika, 2013).pp.114
} 
politics, law, protection and overcoming violence and trafficking of women and children. The Integrated Service Center for Empowering Women and Children is a forum for women's empowerment and child protection on the basis of society. In carrying out its duties, P2TP2A has some positions in accordance with the needs and issues to be addressed.

The functions of this institution are; 1) providing various services for the community both physical and non-physical (information, referrals, consultation/counseling, skills training), 2) conducting trainings for cadres who have a great commitment and concern for women and children's problems in all fields, and 3) collaborating and participating in providing services to the community in order to improve the quality of life and protection for women and children.

The general objective of this institution is to contribute to the realization of gender equality by integrating strategies in various integrated service activities to improve women' conditions, roles and protection as well as provide welfare and protection for children in Kuningan District. The specific purposes of this institution are; 1 ) to provide information related to women and children, including disaggregated data for people in need, 2) to encourage the availability of facilities and infrastructure and the various types of services needed by women and children by providing stakeholders of women and children observers in Kuningan District, and 3) to build a dialogue mechanism between the community, government and the business world so that cooperation/partnership to support the existence of P2TP2A can be established ${ }^{8}$.

The expected results of this team are; 1) the formation of P2TP2A which functions as a gender and child information center, 2) the availability of integrated services and mediation institutions for women and children empowerment in order to improve women's quality of life, welfare and child protection, and women and children's skills and independence, 3) the establishment of partnerships between government, community organizations, and business world with the community in fulfilling women and children's needs, and 4) the establishment of a mechanism for dialogue, communication and partnerships

\footnotetext{
${ }^{8}$ Bupati Kuningan, Fungsi dan Peran P2TP2A, Teks Pidato, 2016
}

between government, community, and business world. Furthermore, some efforts that can be done by the regional government to prevent human trafficking are: improving public awareness to prevent trafficking through socialization, expanding job opportunities through entrepreneurship skills training, economic empowerment, etc., increasing children's educational participation both formal and informal, and collaborating across Regencies/Provinces in order to prevent and handle human trafficking.

\section{CONCLUSION}

1. Human Trafficking has been regulated in Law Number 21 of 2007 concerning the Eradication of Human Trafficking (PTPPO), the Establishment of Integrated Service Centers based on Government Regulation Number 9 of 2008 concerning the procedures and mechanisms of integrated services for witnesses or victims of TPPO, as well as the establishment of PTPPO Task Force consisting of various elements of the government and the community based on Presidential Regulation Number 69 of 2008 concerning Task Force for TPPO Prevention and Handling.

2. Human trafficking occurs in Kuningan District due to several factors, namely economic, social and cultural factors, which are then accumulated in the form of poverty, lack job opportunities, low education background, and the desire to change lives quickly.

3. The policy of Kuningan District Regional Government in an effort to prevent human trafficking has not been carried out optimally. The regulation is only in the form of a District Head's Decree concerning the Establishment of an Integrated Service Center for Empowering Women and Children (P2TP2A). This institution is a forum for women and children in an effort to provide information and services in the fields of education, health, economy, politics, law, protection and overcoming violence and trafficking of women and children.

\section{SUGGESTION}

1. Regional Regulation on Human Trafficking needs to be established so that the regional 
government has a legal basis for dealing with human trafficking cases.

2. Regional government should make serious efforts to overcome poverty and unemployment which are ones of the causes of human trafficking.

3. The Integrated Service Center for Empowering Women and Children should be an independent institution and have enough human resources so that it can work optimally.

\section{REFERENCES}

Arif Gorista, (1993). Masalah Korban Kejahatan, Akademi Pressindo, Jakarta,

Endang Sutrisno, (2007). Bunga Rampai Hukum dan Globalisasi, Genta Press, Jogjakarta

Esmi Warassih, (2005). Pranata Hukum Sebuah Telaah Sosiologis, Suryandaru Utama, Semarang

Farid Muhammad, (2000). Masalah Definisi : Perdagangan manusia, Makalah, Jogjakarta

Farhana, (2010). Aspek Hukum Perdagangan Orang, Sinar Grafika, Jakarta

Henny Nuraeny, (2011). Tindak Pidana Perdagangan Orang, Sinar Grafika, Jakarta

Hilman Hadikusuma, (1986). Antropologi Hukum Indonesia, Penerbit Alumni, Bandung

Haris Budiman dan Gios Adhyaksa. (2015). Implementasi Penerapan UndangUndang Nomor 13 Tahun 2006 Tentang Perlindungan Saksi Dan Korban (Sudi Di Polres Kuningan). ISSN 2354-5976 Vol. 02 Nomor 01 Januari 2015, pp. 49-66. https://doi.org/10.25134/unifikasi.v2i1.2 $\underline{5}$

Haris Budiman dan Suwari Akhmaddhian (2014). Implementasi Reformasi Birokrasi Bidang Perizinan Pananaman Modal Di Kabupaten Kuningan. ISSN 2354-5976 Vol. 01 Nomor 01 Januari 2014,pp. $1-19$. https://doi.org/10.25134/unifikasi.v1i1.2 $\underline{8}$

Kamudin, (2015). Implementasi Kebijakan Perdagangan Orang,Jurnal Ilmu Hukum Hermeneutika, Jilid 1 Nomor 1

Mohammad Dermawan, (2000). Strategi Pencegahan Kejahatan, PT Aditya Bakti, Bandung
Ronny Hanityo Soemitro, (1990). Metode Penelitian Hukum dan Jurimetri, Galia Indonesia, Jakarta

Son Haji, (2003). Aspek Hukum Perlindungan TKI di Luar Negeri, Jurnal masalah Masalah Hukum, Universitas Diponegoro, Semarang

Soetandyo Wignjosoebroto, Silabus metode penelitian Hukum, Program Pascasarjana Universitas Airlangga, Surabaya

Suwari Akhmaddhian (2014). Analisis Pertanggungjawaban Tenaga Medis Yang Melakukan Tindak Pidana Malpraktek Menurut Uu Nomor 36 Tahun 2009 Tentang Kesehatan. ISSN 2354-5976 Vol. 01 Nomor 01 Januari 2014, hlm. 34-49. https://doi.org/10.25134/unifikasi.v1i1.3 $\underline{3}$

Umar Said Sugiarto, (2013). Pengantar Hukum Indonesia, Sinar Grafika, Jakarta

Terence H Hull, Endang S, Gavin W Jones, (1997). Pelacuran di Indonesia, cetakan I, Pustaka Sinar Harapan, Jakarta 